\title{
High throughput monoclonal antibody generation by immunizing multiple antigens
}

\author{
LIU Ying ${ }^{1 *}$, WANG YunDan ${ }^{2}$, LIU Jing $^{1}$, ZUO Wei ${ }^{1}$, HAO Lu ${ }^{1}$, ZHANG LiLi $^{3} \&$ ZHEN Bei ${ }^{1}$ \\ ${ }^{1}$ State Key Laboratory of Proteomics, Beijing Proteome Research Center, Beijing 102206, China; \\ ${ }^{2}$ Beijing Institutes of Life Science, Chinese Academy of Sciences, Beijing 100101, China; \\ ${ }^{3}$ Anhui Medical University, Hefei 230032, China
}

Received February 18, 2014; accepted April 19, 2014; published online June 19, 2014

\begin{abstract}
Recognizing proteins via the production of highly specific monoclonal antibodies (mAbs) is crucial to identifying proteins for proteomic research. However, traditional mAb generation is time-consuming with low efficiency. In this study, we assessed the high throughput method of producing mAbs by immunizing mice with multiple antigens in order to obtain hybridomas against these multiple antigens in one cell fusion. We selected eight proteins that play important roles in human physiological or pathological processes. These proteins were mixed and simultaneously administered to one mouse. We observed the immunizing period for $10 \mathrm{~d}$, and determined the effect of liquid medium and semi-solid medium in hybridoma generation. As a result, all eight immunogens induced antibodies in the immunized mouse in one cell fusion, we obtained hybridomas specific to all eight proteins by enzyme-linked immuno sorbent assay (ELISA) screening, hybridomas against five out of eight showed specific positive in Western-blotting assays. This indicates that we generated mAbs specific to eight proteins in one cell fusion, greatly increasing the efficiency of mAb generation. Furthermore, we observed that hybridomas selected from the liquid medium and semi-solid medium showed different reactivity to antigens. Our study established high-throughput and time-saving methods for production of mAbs. These results provide alternative approaches for increasing the efficacy of mAb generation.
\end{abstract}

\section{high throughput, mAb, multiple antigen immunization, ELISA}

Citation: $\quad$ Liu Y, Wang YD, Liu J, Zuo W, Hao L, Zhang LL, Zhen B. High throughput monoclonal antibody generation by immunizing multiple antigens. Sci China Life Sci, 2014, 57: 710-717, doi: 10.1007/s11427-014-4688-0

Through the development of proteomics research, thousands of proteins can be identified by antibodies (Abs) for protein separation and enrichment, functional verification, analysis of protein-protein interactions, recognition of post-translational modifications and so on [1-3]. Therefore, Abs are becoming indispensable reagents in protein research. Traditional antibody production is time-consuming and inefficient. Numerous attempts to increase the speed of monoclonal antibody (mAb) generation and throughput have been reported. Ning et al. [4] immunized mice with fractioned plasma proteins and identified the corresponding antigens by immunoprecipitation/mass spectrum. Ju et al. [5] im-

*Corresponding author (email: liuying1342@163.com) munized mice with fractionated mitochondrial proteins and identified the mAb specificity using cDNA expression library screening combined with Mass spectrum. Some researchers immunized mice with a protein mixture and screened mAb specificity by microarray [6-8] and flow cytometry analysis [9]. Other non-hybridoma approaches such as target-selective joint polymerase chain reactions [10] and phage display $[11,12]$ have also been reported, however, these methods are based on antibody repertoire rather than inducement by immunization.

For this study, we used a mixture of eight physiologically or pathologically relevant proteins with low pairwise similarity to simultaneously immunize mice. As a result, we 
obtained positive hybridomas against all the immunized proteins at 10 days post immunization. We collected mono-specific antibodies against five antigens demonstrated in both ELISA and Western-blotting assays. Our study may establish a high throughput platform for $\mathrm{mAb}$ generation to meet the increasing demand for antibodies in protein-related research.

\section{Materials and methods}

\subsection{Protein expression and purification}

Eight proteins were selected for immunization: tumor protein p53 (TP53, UniProt ID: P04637), c-myc (UniProt ID: P01106), S100 calcium binding protein A8 (S100A8, UniProt ID: P05109), S100 calcium binding protein A9 (S100A9, UniProt ID: P06702), pCAF (UniProt ID: Q92831), Calcitonin (PCT, full length named PCT-1, truncated fragment from 52 amino acid (Aa) to the C-terminal named PCT-2, UniProt ID: P01258), and protein tyrosine phosphatase PTEN (PTEN, UniProt ID: P60484). Gene encoding pCAF was constructed with vector pET-28a(+) (Novagen, Germany), while others were constructed with the vector pET-32a(+) (Novagen). The restriction enzyme of vectors PCT-1, PCT-2, TP53, c-myc and pCAF are EcoR I and Xho I, and the restriction enzyme of vectors S100A8, S100A9 and PTEN are BamH I and Xho I. Proteins were expressed in Escherichia coli BL21 (DE3) strains by isopropyl $\beta$-D-1-thiogalactopyranoside (IPTG) induction. The $E$. coli was collected by centrifugation and resuspended with binding buffer $\left(20 \mathrm{mmol} \mathrm{L}^{-1}\right.$ sodium phosphate, 500 mmol L ${ }^{-1} \mathrm{NaCl}, 20-40 \mathrm{mmol} \mathrm{L}^{-1}$ imidazole, $1 \%$ Triton $\mathrm{X}-100, \mathrm{pH}$ 7.4). The samples were treated by sonication for about $10 \mathrm{~min}$ and centrifuged, and the supernatant was then collected and purified with Ni Sepharose ${ }^{\mathrm{TM}} 6$ Fast Flow (GE Healthcare, USA) according to the manufacturer's instructions as follows: the column was washed with distilled water five times the column's volume, then balanced with at least five times the column's volume of binding buffer; the sample was repeatedly loaded into column three times, and then washed with 5-10 column volumes of binding buffer; the sample was finally eluted with elution buffer $(20 \mathrm{mmol}$ $\mathrm{L}^{-1}$ sodium phosphate, $500 \mathrm{mmol} \mathrm{L} \mathrm{NaCl}^{-1}$ 50-500 mmol $\mathrm{L}^{-1}$ imidazole, $1 \%$ Triton $\left.\mathrm{X}-100, \mathrm{pH} 7.4\right)$. The purified proteins were analyzed by sodium dodecyl sulfate polyacrylamide gel electrophoresis (SDS-PAGE).

To avoid the selection of mAbs against the protein tags, all proteins were expressed in the pGEX-4T-1 vector with a GST tag that was used for Ab screening. The GST-tagged protein was purified as follows: E. coli was collected by centrifugation and resuspended with lysis buffer $(50 \mathrm{mmol}$ $\mathrm{L}^{-1}$ Tris-HCl pH 8.0, $0.2 \mathrm{mmol} \mathrm{L}^{-1}$ EDTA, $100 \mathrm{mmol} \mathrm{L}^{-1}$ $\mathrm{NaCl}, 1 \%$ Triton X-100, $1 \mathrm{mmol} \mathrm{L}^{-1}$ DTT, $100 \mu \mathrm{g} \mathrm{mL}$ PMSF). The samples were treated by sonication for about
$10 \mathrm{~min}$ and centrifuged, the pellet was collected and washed with lysis buffer containing 1,2 and 4 mol L ${ }^{-1}$ Urea, respectively, the pellet was collected as the inclusion body after centrifugation and dissolved by lysis buffer containing $8 \mathrm{~mol} \mathrm{~L}^{-1}$ urea, then analyzed by SDS-PAGE.

\subsection{Immunization and production of $\mathrm{mAb}$}

Eight purified His-tagged proteins were mixed with $10 \mu \mathrm{g}$ each, emulsified with Freund's complete adjuvant and were immunized to mice simultaneously. After $10 \mathrm{~d}$, mice were boosted with half amount ( $5 \mu \mathrm{g}$ each) of the same antigens, emulsified with Freund's incomplete adjuvant. Three days after boosting, spleen cells of immunized mice were fused with myeloma partner Sp2/0 cells following standard protocols [4]. A portion of the fusion cells from the 10-day immunization were cultured in a liquid medium and the rest were cultured in a semi-solid medium to compare the efficacy of hybridoma generation in each medium.

\subsection{ELISA}

\subsubsection{Antibody titer determination}

The eight GST-tagged proteins were diluted to $1 \mu \mathrm{g} \mathrm{mL}$ by coating buffer $\left(\mathrm{Na}_{2} \mathrm{CO}_{3}, 1.59 \mathrm{~g} ; \mathrm{NaHCO}_{3}, 2.93 \mathrm{~g} ; \mathrm{NaN}_{3}\right.$, $0.2 \mathrm{~g}$, dissolved in $1 \mathrm{~L}$ distilled water), separately coated to 96-well plates with $100 \mu \mathrm{L} /$ well and stored at $4{ }^{\circ} \mathrm{C}$ overnight. The coated 96-well plates were washed three times with phosphate balanced solution with $0.05 \%$ tween-20 (PBST), then blocked with $5 \%$ skim milk at $37^{\circ} \mathrm{C}$ for $1 \mathrm{~h}$, and washed again with PBST three times. Anti-serum from immunized mice underwent 100-fold dilution and then three-fold serial dilutions. The diluted sera were added to the antigen-coated plate as the primary antibody, incubated at $37^{\circ} \mathrm{C}$ for $1 \mathrm{~h}$, and then washed with PBST. HRPconjugated goat anti-mouse IgG (Jackson, USA) was diluted and added to the plates according to the instructions for use. After the plates were incubated at $37^{\circ} \mathrm{C}$ for $30 \mathrm{~min}$, TMB chromogen solution (Sigma, USA) was added and the reaction was stopped using $0.5 \mathrm{~mol} \mathrm{~L}{ }^{-1} \mathrm{H}_{2} \mathrm{SO}_{4}$. The plates were finally read at $450 \mathrm{~nm}$ using a micro-plate reader.

\subsubsection{Antibody screening}

Hybridomas were selected using two rounds of screening. In the first round screening, equal volumes of eight GST-tagged proteins $\left(1 \mu \mathrm{g} \mathrm{mL} \mathrm{m}^{-1}\right.$, described in "Antibody titer determination") were mixed and the mixture was used to coat 96-well plates with $100 \mu \mathrm{L} /$ well and stored at $4^{\circ} \mathrm{C}$ overnight. The coated plates were washed and blocked as described. The supernatant of hybridoma was added to the antigen-coated plates as the primary antibody and was treated following steps described previously. The positive clones were selected in the second round screening. In the second round screening, eight GST-tagged proteins $(1 \mu \mathrm{g}$ 
$\mathrm{mL}^{-1}$, described in "Antibody titer determination") were used to separately coat 96-well plates with $100 \mu \mathrm{L} /$ well and stored at $4^{\circ} \mathrm{C}$ overnight. Supernatant of Hybridomas was added to the antigen-coated plates as the primary antibody and treated following the same procedure as above.

\subsection{Semi-solid medium}

The medium was made using $4 \%$ methyl cellulose (Sigma) in triple-distilled water that was dissolved and autoclaved, then mixed with an equal volume of 2xRPMI 1640 (Hyclone, USA) basal liquid medium and stirred for 3-4 d and stored at $4^{\circ} \mathrm{C}$. When used for cell culture, the medium was supplemented with $20 \%$ fetal bovine serum. Hypoxanthineaminopterin-thymidine (HAT, Sigma) and feeder cells were mixed with fusion cells and poured into dishes. After culturing for about one week, the clones were visible and transferred to 96-well plates and kept in liquid media for ELISA detection.

\subsection{Western blotting}

Eight GST-tagged proteins were separately loaded on SDS-PAGE gel and electrophoretically transferred to a PVDF membrane. The membrane was incubated with supernatant of hybridoma that was selected based on screening via two rounds of ELISA detection described above. Membranes were incubated at $37^{\circ} \mathrm{C}$ for $2 \mathrm{~h}$ and washed with PBST then incubated with HRP-conjugated goat anti-mouse IgG (Jackson) at $37^{\circ} \mathrm{C}$ for $1 \mathrm{~h}$. The signal was detected using an ECL Western-blotting kit (Pierce, USA).

\section{Results}

\subsection{Protein expression and purification}

All eight recombinant proteins were expressed in E. coli, purified, and analyzed by SDS-PAGE. All eight His-tagged proteins used for immunizing and GST-tagged proteins for $\mathrm{Ab}$ screening are presented in Figure 1. All proteins expressed correct molecular weight and the purity of each purified protein was $>90 \%$ according to analysis by the "Quantity One" software (Bio-Rad, USA). Homologies of any two antigens are listed in Table 1. PCT-1 and -2 have a higher homology $(64 \%)$ because they share a common amino acid sequence but all other proteins' homology (Aa sequence) is $\leqslant 34 \%$.

\subsection{Antibody titer determination}

Antibody titer after immunization was determined by limiting dilution method using the corresponding GST-tagged proteins. The highest dilution of anti-serum with positive results is listed in Table S1 in Supporting Information and
Table 1 The amino acid sequence homology between any two of the eight proteins (\%)

\begin{tabular}{|c|c|c|c|c|c|c|c|c|}
\hline & c-Myc & pCAF & PCT-1 & РCT-2 & PTEN & S100A8 & S100A9 & TP53 \\
\hline c-Myc & & 25 & 23 & 26 & 15 & 20 & 21 & 12 \\
\hline pCAF & 25 & & 34 & 31 & 15 & 15 & 18 & 21 \\
\hline PCT-1 & 23 & 34 & & 64 & 16 & 23 & 16 & 22 \\
\hline PCT-2 & 26 & 31 & 64 & & 18 & 9 & 9 & 24 \\
\hline PTEN & 15 & 15 & 16 & 18 & & 23 & 18 & 16 \\
\hline S100A8 & 20 & 15 & 23 & 9 & 23 & & 28 & 19 \\
\hline S100A9 & 21 & 18 & 16 & 9 & 18 & 28 & & 22 \\
\hline TP53 & 12 & 21 & 22 & 24 & 16 & 19 & 22 & \\
\hline
\end{tabular}
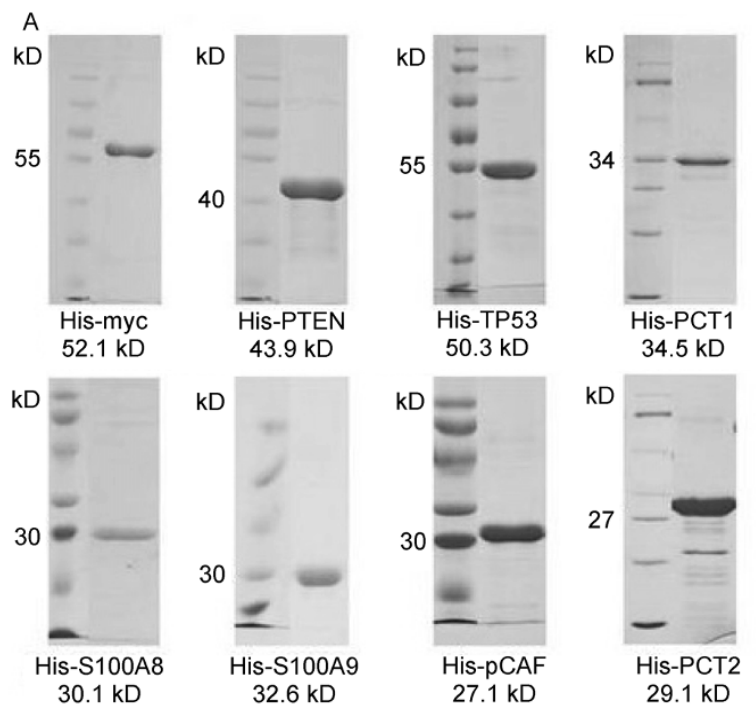

B
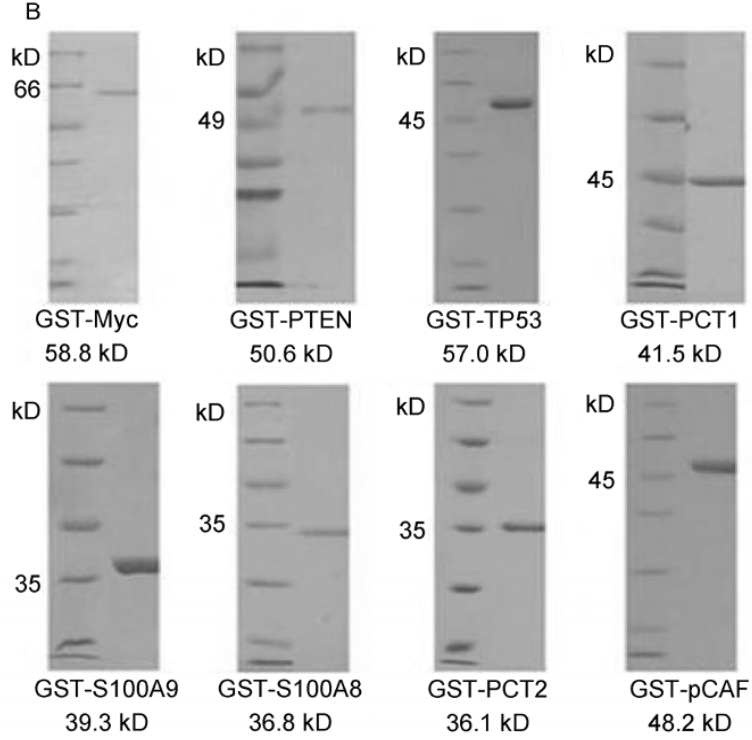

Figure 1 SDS-PAGE analysis of eight purified recombinant proteins. The gel is composed of 5\% stacking gel and $12 \%$ separating gel, after electrophoresis, the separating gel was stained with Coomassie brilliant blue R-250. The left lane in each picture is protein standards. A, His-tagged purified proteins. B, GST-tagged purified proteins.

the $\lg$ of highest dilution ratio is shown in Figure 2. The results showed all eight immunized antigens induced spe- 


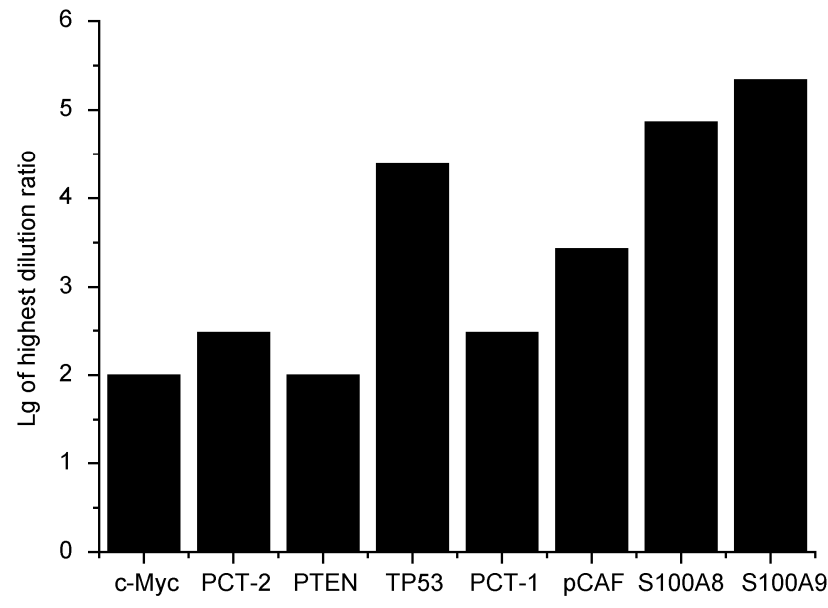

Figure 2 Antibody titer after immunization was determined by limiting dilution method, and detected by ELISA. The titer was indicated in $1 g$ of highest dilution ratio with positive result.

cific antibodies in serum from immunized mice, but the antibody titer against each protein is different, S100A9 and S100A8 induced higher antibody titer while c-myc and PTEN induced the lowest antibody titer.

\subsection{Antibody screening by ELISA assay}

\subsubsection{The first screening}

After cell fusion, hybridomas were screened with a mixture of eight GST-tagged proteins. Two thousand two hundred and fifty-six wells (hybridomas) were tested in total and 129 of them showed positive results in the first ELISA screening (Table 2).

\subsubsection{The second screening}

The positive wells (hybridomas) in the first screen were further selected in the second screening using eight GST-tagged proteins to confirm the corresponding antigen of the hybridomas. One hundred and twenty-nine wells (hybridamas) from the first screen were tested, 87 of which showed positive in different reactive patterns. Among the 87 hybridomas, 29 were mono-specific to single protein, 50 were reactive to two proteins, two were reactive to three proteins, one was reactive to four proteins, one was reactive to five proteins, one was reactive to six proteins, one was reactive to seven proteins, and two were reactive to all the eight proteins (Table S2 in Supporting Information), the optical density value of all 87 clones and their reactivity are

Table 2 Summary of detected well number and positive well number in two rounds of ELISA assay

\begin{tabular}{|c|c|c|c|}
\hline & & $\begin{array}{l}\text { Positive wells in } \\
\text { the } 1 \text { st screening }\end{array}$ & $\begin{array}{l}\text { Positive wells in } \\
\text { the } 2 \text { nd screening }\end{array}$ \\
\hline Total detected wells & 2256 & 129 & 87 \\
\hline Wells from liquid medium & 1880 & 103 & 78 \\
\hline Wells from semi-solid medium & 376 & 26 & 9 \\
\hline
\end{tabular}

listed in Table S5 in Supporting Information. The number of positive hybridomas per antigen is illustrated in Figure 3. As the results show, S100A8 and S100A9 account for the largest number of positive hybridomas; moreover, a significant portion of these hybridomas are cross-reactive to both S100A8 and S100A9 proteins. Notably, pCAF induced more mono-specific hybridomas.

Results of partial mono-specific clones (hybridomas) in the second ELISA screening were collected (Table S3 in Supporting Information) and shown in Figure 4. From the results, the corresponding antigens of different hybridomas are easily understood. For example, the corresponding antigen of Clone 1 is c-Myc, the corresponding antigen of Clone 2 is TP53 and so on. Clone 6 reacted to PCT-1 and PCT-2, indicating that its corresponding antigen is the common fragment of PCT-1 and PCT-2, while Clone 7 reacted to the unique part of PCT-1.

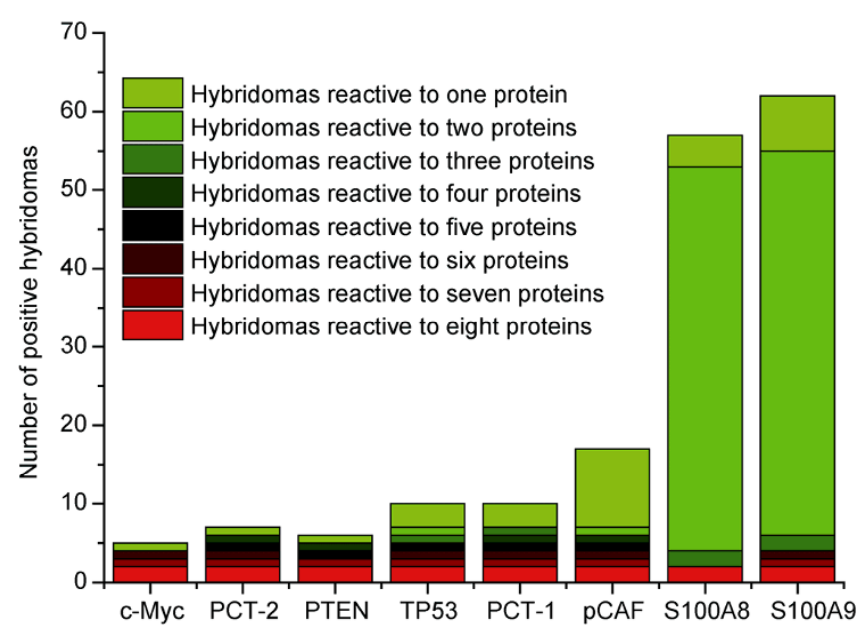

Figure 3 Hybridomas positive in the first screen were detected in the second round by using each single GST-tagged protein. Positive hybridomas against the respective antigen (Table S2 in Supporting Information) were organized and shown as column chart.

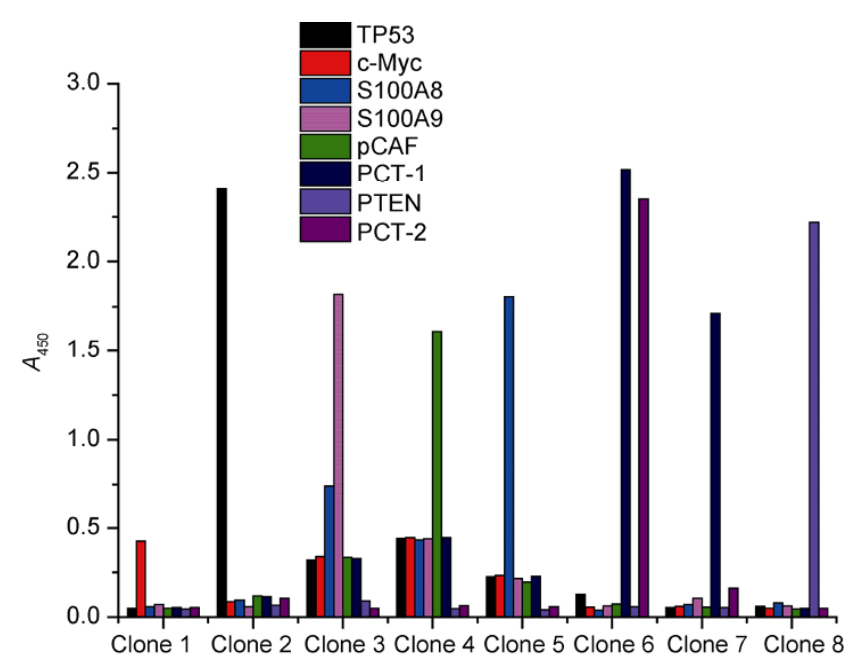

Figure 4 Partial results of mono-specific clones (Table S3 in Supporting Information) in the second round of ELISA screening. 


\subsection{Comparison of the two media}

In order to compare the effect of semi-solid media and the classical liquid media in hybridoma generation, the fusion cells were cultured with these two kinds of media respectively and evaluated in two rounds of ELISA screening as described. Three hundred and seventy-six wells cultured in semi-solid medium and 1880 wells cultured in liquid medium (Table 2) were detected in the first round of screening. As the result, 26 wells $(6.9 \%)$ from semi-solid media and 103 wells $(5.4 \%)$ from liquid media showed positive. The positive wells were tested in the second round screening. From these results, nine out of 26 wells cultured by semi-solid medium showed specificity to one, six, seven, and eight kinds of proteins, while 78 out of 103 wells cultured by classical liquid medium showed specificity to one, two, three, four, five, and eight kinds of proteins (Table S4 in Supporting Information; Table 2). These results are summarized in Figure 5. The hybridomas that only reacted to a single protein are called "mono-specific" hybridoma, those that reacted to multiple proteins, "poly-reactive" hybridoma, and those that reacted to limited proteins, "oligoreactive" hybridoma [13,14]. We have observed that the classical liquid medium cultured mono-reactive hybridomas, "oligo-reactive" hybridomas and poly-reactive hybridomas, while the semi-solid medium did not select the "oligo-reactive" hybridomas.

\subsection{Western blotting}

Specificity of the mono-specific hybridomas in ELISA was further verified by Western blotting, two irrelative proteins
(MLH1, NP_000240.1 and Clu, NP_000305.3) were added as negative control (Figure 6). From the results, hybridomas mono-specific to five proteins (S100A8, S100A9, pCAF, PCT-1 and PCT-2) were verified. All antibodies reacted with a single antigen and did not cross-react with the other seven proteins. The antibody in Figure $6 \mathrm{C}$ showed positive for both PCT-1 and -2, suggesting the antibody is specific to the common fragment of PCT-1 and -2. Antigens TP53 and pCAF were partially degraded, which led to multiple bands in Western blotting (Figure 6D and E).

\section{Discussion}

Antibodies are an important tool in protein related research. Many countries and institutes have organized $\mathrm{Ab}$ related projects such as "ProteomeBinders", a new European consortium to establish a comprehensive resource of wellcharacterized affinity reagents, including antibodies [15]. The Human Proteome Organization has officially launched a global Human Proteome Project (HPP) designed to map the entire human protein set [16-18]. HPP research groups will use the three working pillars for the project, one of which is the antibody capture pillar $[19,20]$. Consequently, the antibody/protein capture resource committee was established in 2012. With the in-depth development of human proteomics, the project for preparation of antibodies against all human proteins has been mentioned in the agenda. However, the number of human proteins is enormous because of posttranslational modification, alternative splicing, mutation and so on. Moreover, each protein requires differ-

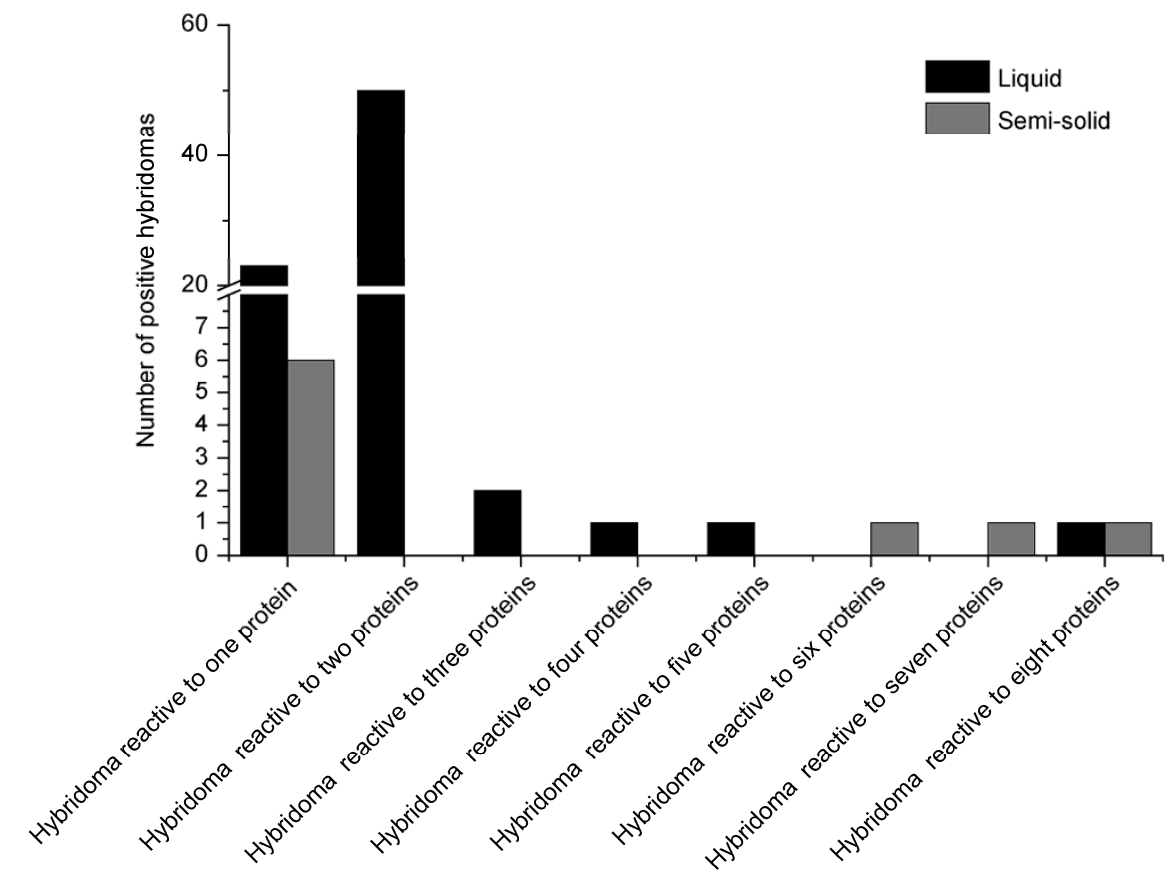

Figure 5 Comparing the effect of liquid and semi-solid media to hybridoma generation. 

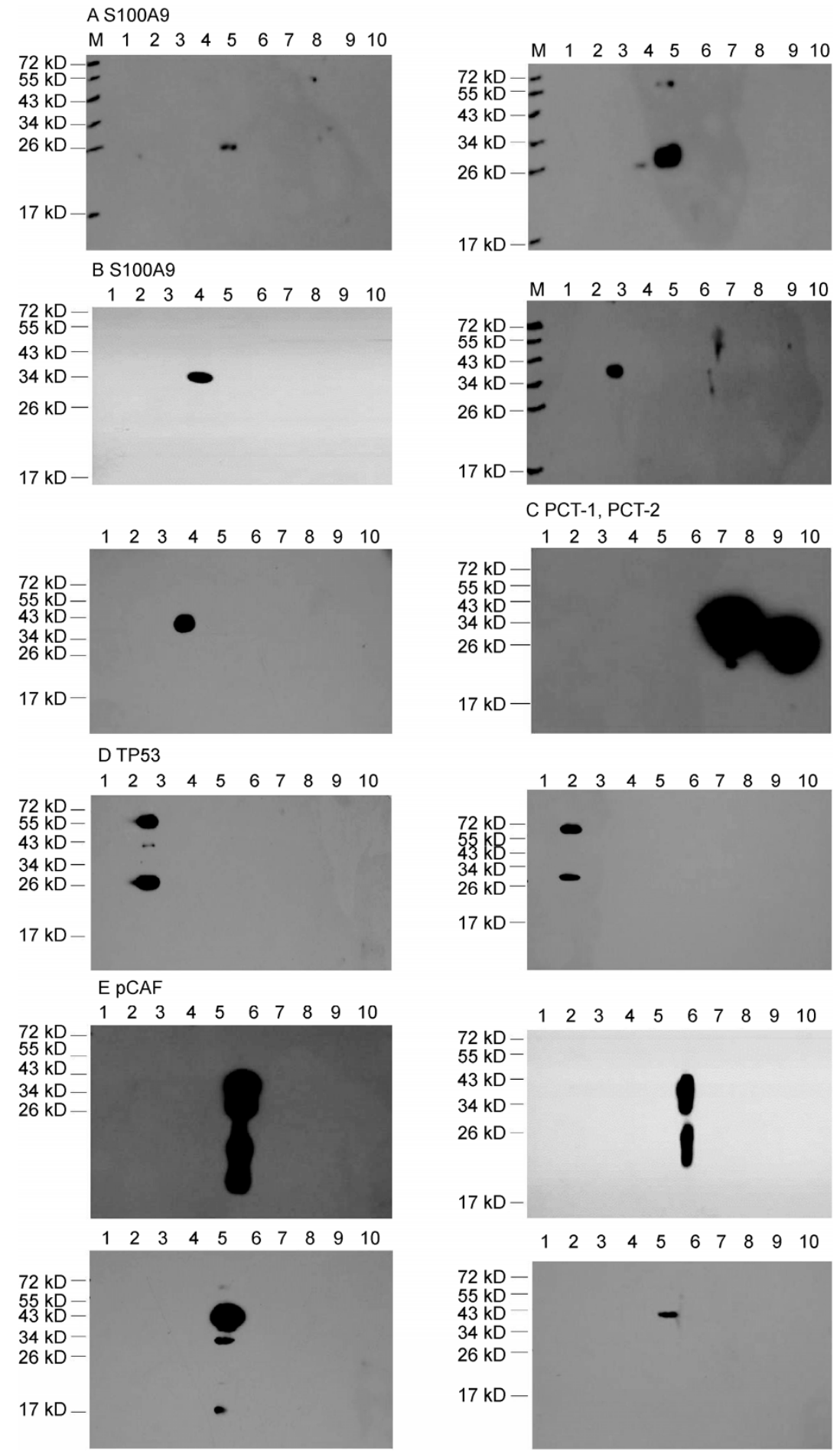

Figure 6 After two rounds of ELISA screening, partial mono-specific clones were further identified in Western blot. All gels were loaded as follows: Lane 1, MLH1; Lane 2, TP53; Lane 3, Myc; Lane 4, S100A8; Lane 5, S100A9; Lane 6, pCAF; Lane 7, Clu; Lane 8, PCT-1; Lane 9, PTEN; Lane 10, PCT-2.

ent antibodies that are suitable for different applications (Western blotting, immunoprecipitation, immunohistochemistry, immunofluorescence, flow cytometry, etc.). For these reasons, a high throughput method that can rapidly generate antibodies is urgently needed. In our previous research, our group has immunized mice with four known proteins and screened for mAbs with ELISA and protein array [8]. In this study, we expanded the antigen set to eight kinds of proteins. For this project, we made efforts to generate mAbs that are characterized by both high throughput and fast immunization. We were able to produce hybridomas specific against all immunized proteins verified by 
ELLSA. However, we could not produce positive hybridomas against c-Myc and PTEN that could be verified by Western-blotting. This is probably because c-Myc and PTEN induced only a weak immune-response in the mice (the antibody titers are all 1:100), resulting in very few specific B cells. Fusion cells were cultured both in liquid RPMI-1640 and semi-solid medium to compare the effect to hybridomas reactivity. The liquid medium cultured monoreactive hybridomas, "oligo-reactive" hybridomas and poly-reactive hybridomas, while the semi-solid medium lost the "oligo-reactive" hybridomas. A multireactive antibody was reported in the preimmune repertoire that could bind to several unrelated antigens [21] and cause immunoassay interference [22]. An oligo-reactive $\mathrm{Ab}$ is the intermediate form when a poly-reactive $\mathrm{Ab}$ converts to mono-reactive $\mathrm{Ab}$ $[13,14]$, suggesting that as an intermediate form during antibody affinity maturation process, the hybridoma is not stable and is unable to survive in semi-solid medium. However, to some extent, this reduced workload is consistent with our initial goal.

Here antigens S100A8 and S100A9 induced a large proportion of positive clones that showed cross-reactivity to both of them (Table S2 in Supporting Information; Figure 3). S100A8 and S100A9 are co-expressed in the event of acute or chronic inflammation, and form a hetero-dimer complex for functioning under physiological condition. It is reported that these two proteins have high similarity in spatial conformation [23], which may cause many initially induced antibodies not to distinguish them well. Compared to others, antigen pCAF induced more mono-specific clones when its high antigenicity is taken in consideration. Thus, to increase the variety of mono-reactive clones in the case of immunization of multiple antigens, antigenicity should be considered for inducing B-cells against the given immunogen. Moreover, high homology in both amino acid sequence and spatial conformation of antigens should be avoided for properly rising of multi-reactive clones. Besides, from our results, the semi-solid medium may be a good way not only because of its selectivity for the "oligo-reactive clones", but also because a single clone can be easily judged compared with the liquid medium. Thus, the "multi-reactive" caused by "multiple clones" can be quickly distinguished. For obtaining more mono-reactive clones, enough immune time is necessary. It is reported that polyreactive antibodies are the predominant antibodies produced by early B cell precursors and play a similar role in natural immunity [14], suggesting that most polyreactive antibodies may appear in the early stage of immunization. Therefore, our short immunization period of $10 \mathrm{~d}$ may not be enough for producing more mono-reactive antibodies. The aforementioned points may increase the possibility of getting sufficient monoclonal antibodies against each antigen. Such method that allows for antigen selection of multiple proteins and produces high-quality antibodies is essential to high throughput monoclonal antibody production.

\section{Conclusion}

We immunized mice with eight proteins important in research and clinical use and obtained mAbs mono-specific to eight antigens in ELISA assay. Among them, mAbs against five antigens showed positive both in ELISA and Western-blotting detection. This not only provides a reliable approach to high throughput monoclonal antibody production, but also saves time and labor costs in proteome research for identification of target proteins.

We thank Zhang Xia and Xu MingHui (Harbin Medical University) for assistance with picking clones from the semi-solid medium when they visited our lab, Liu YangYang (technician of our lab) for help of data reduction and Tong RuiEn (college student of University of Pennsylvania) for revision of the draft during his summer internship in our lab. This work was supported by the National Basic Research Program of China (2011CB915502), State Key Laboratory of Proteomics Project (SKLP Y200907) and National High Technology Research and Development Program of China (2012AA020201).

1 Björling E, Uhlén M. Antibodypedia, a portal for sharing antibody and antigen validation data. Mol Cell Proteom, 2008, 7: 2028-2037

2 Joos T. Affinity-MS-Methods and applications in proteomics research. Proteomics, 2009, 9: 1418-1419

3 Uhlén M. Affinity as a tool in life science. Biotechniques, 2008, 44: 649-654

4 Ning Y, Wang Y, Li Y, Hong Y, Peng D, Liu Y, Wang J, Hao W, Tian X, Wu F, Dong W, Wang L, Wu Q, Liu X, Gao J, He F, Qian X, Sun Q, Li M. An alternative strategy for high throughput generation and characterization of monoclonal antibodies against human plasma proteins using fractionated native proteins as immunogens. Proteomics, 2006, 6: 438-448

5 Ju YF, Yang JJ, Liu R, Liu X, Du X, Liu L, Chen Z, Chi J, Liu S, Gao Y, Gao J, Jiao S, He F, Sun Q. Antigenically dominant proteins within the human liver mitochondrial proteome identified by monoclonal antibodies. Sci China Life Sci, 2011, 54: 16-24

6 Ma D, Baruch D, Shu Y, Yuan K, Sun Z, Ma K, Hoang T, Fu W, Min L, Lan ZS, Wang F, Mull L, He WW. Using protein microarray technology to screen anti-ERCC1 monoclonal antibodies for specificity and applications in pathology. BMC Biotechnol, 2012, 12: 88

7 Moller I, Marcus SE, Haeger A, Verhertbruggen Y, Verhoef R, Schols H, Ulvskov P, Mikkelsen JD, Knox JP, Willats W. High-throughput screening of monoclonal antibodies against plant cell wall glycans by hierarchical clustering of their carbohydrate microarray binding profiles. Glycoconj J, 2008, 25: 37-48

8 Yu Z, Liu L, Yu X, Chi J, Han H, Liu Y, He W, Sun Q, Gao J, Xu D. High-throughput antibody generation using multiplexed immunization and immunogen array analysis. J Biomol Screen, 2010, 15: 1260-1267

9 Smith RA, Giorgio TD. Cell-based screening: a high throughput flow cytometry platform for identification of cell-specific targeting molecules. Comb Chem High Throug Screen, 2004, 7: 141-151

10 Megumi Y, Nobuyuki K, Masaharu I. Target-selective joint polymerase chain reaction: a robust and rapid method for high-throughput production of recombinant monoclonal antibodies from single cells. BMC Biotechnol, 2011, 11: 75

11 Clementi N, Mancini N, Solforosi L, Castelli M, Clementi M, Burioni R. Phage display-based strategies for cloning and optimization of monoclonal antibodies directed against human pathogens. Int J Mol Sci, 2012, 13: 8273-8292

12 Cyranka-Czaja A, Otlewski J. A novel, stable, helical scaffold as an alternative binder-construction of phage display libraries. Acta Biochim Polon, 2012, 59: 383-390 
13 Ning Y, Li Y, Li M. Research on mechanism of different reactive antibody producing. Chin J Immunol, 2006, 22: 880-882

14 Notkins AL. Polyreactivity of antibody molecules. Trends Immunol, 2004, 25: 174-179

15 Taussig MJ, Stoevesandt O, Borrebaeck CAK, Bradbury AR, Cahill D, Cambillau C, de Daruvar A, Dübel S, Eichler J, Frank R, Gibson TJ, Gloriam D, Gold L, Herberg FW, Hermjakob H, Hoheisel JD, Joos TO, Kallioniemi O, Koegl M, Konthur Z, Korn B, Kremmer E, Krobitsch S, Landegren U, van der Maarel S, McCafferty J, Muyldermans S, Nygren PA, Palcy S, Plückthun A, Polic B, Przybylski M, Saviranta P, Sawyer A, Sherman DJ, Skerra A, Templin M, Ueffing M, Uhlén M. ProteomeBinders: planning a European resource of affinity reagents for analysis of the human proteome. Nat Methods, 2007, 4: 13-17

16 Legrain P, Aebersold R, Archakov A, Bairoch A, Bala K, Beretta L, Bergeron J, Borchers CH, Corthals GL, Costello CE, Deutsch EW, Domon B, Hancock W, He F, Hochstrasser D, Marko-Varga G, Salekdeh GH, Sechi S, Snyder M, Srivastava S, Uhlén M, Wu CH, Yamamoto T, Paik YK, Omenn GS. The human proteome project: current state and future direction. Mol Cell Proteomics, 2011, 10: M111.009993

17 Paik YK, Jeong SK, Omenn GS, Uhlen M, Hanash S, Cho SY, Lee HJ, Na K, Choi EY, Yan F, Zhang F, Zhang Y, Snyder M, Cheng Y, Chen R, Marko-Varga G, Deutsch EW, Kim H, Kwon JY, Aebersold R, Bairoch A, Taylor AD, Kim KY, Lee EY, Hochstrasser D, Legrain $\mathrm{P}$, Hancock WS. The Chromosome-Centric Human Proteome Project for cataloging proteins encoded in the genome. Nat Biotechnol, 2012, 30: $221-223$
18 Paik YK, Omenn GS, Uhlen M, Hanash S, Marko-Varga G, Aebersold R, Bairoch A, Yamamoto T, Legrain P, Lee HJ, Na K, Jeong SK, He F, Binz PA, Nishimura T, Keown P, Baker MS, Yoo JS, Garin J, Archakov A, Bergeron J, Salekdeh GH, Hancock WS. Standard guidelines for the chromosome-centric human proteome project. J Proteome Res, 2012, 11: 2005-2013

19 Fagerberg L, Oksvold P, Skogs M, Algenäs C, Lundberg E, Pontén F, Sivertsson A, Odeberg J, Klevebring D, Kampf C, Asplund A, Sjöstedt E, Al-Khalili Szigyarto C, Edqvist PH, Olsson I, Rydberg U, Hudson P, Ottosson Takanen J, Berling H, Björling L, Tegel H, Rockberg J, Nilsson P, Navani S, Jirström K, Mulder J, Schwenk JM, Zwahlen M, Hober S, Forsberg M, von Feilitzen K, Uhlén M. Contribution of antibody-based protein profiling to the Human Chromosome-centric Proteome Project (C-HPP). J Proteome Res, 2012, 12: 2439-2448

20 Uhlén M, Oksvold P, Älgenäs C, Hamsten C, Fagerberg L, Klevebring D, Lundberg E, Odeberg J, Pontén F, Kondo T, Sivertsson A. Antibody-based protein profiling of the human chromosome 21. Mol Cell Proteomics, 2012, 11: M111.013458

21 Conger JD, Sage HJ, Corley RB. Correlation of antibody multireactivity with variable region primary structure among murine anti-erythrocyte autoantibodies. Eur J Immunol, 1992, 22: 783-790

22 Levinson SS. Antibody multispecificity in immunoassay interference. Clin Biochem, 1992, 25: 77-87

23 Itou H, Yao M, Fujita I, Watanabe N, Suzuki M, Nishihira J, Tanaka I. The crystal structure of human MRP14 (S100A9), a $\mathrm{Ca}^{2+}$ - dependent regulator protein in inflammatory process. J Mol Biol, 2002, 316: 265-276

Open Access This article is distributed under the terms of the Creative Commons Attribution License which permits any use, distribution, and reproduction in any medium, provided the original author(s) and source are credited.

\section{Supporting Information}

Table S1 Antibody titer after immunization was determined by limiting dilution method; highest dilution ratio with positive result is listed

Table S2 Number of positive clones against each protein in the second round detection

Table S3 Results (partial) of mono-specific clones in the second round screening of ELISA

Table S4 Comparison of two media; number of positive clones against each protein in the second screening is listed

Table S5 The isotype of 87 positive clones

The supporting information is available online at life.scichina.com and link.springer.com. The supporting materials are published as submitted, without typesetting or editing. The responsibility for scientific accuracy and content remains entirely with the authors. 